\title{
ANALISIS KESESUAIAN KONSTITUSI EKONOMI INDONESIA TERHADAP EKONOMI ISLAM
}

\begin{abstract}
Ali Rama1
Makhlani

Abstract. The Similarities of Indonesian Economy Constitution to Islamic Economy. This study invistigates the similarities between the constitution of the Indonesian economy and Islamic economic system. It finds that the constitution of Indonesian economy contained in the 1945 Section 33, 34, 23, 27 and 28 have in common with the Islamic economic system, especially at the basic values, basic principles and instrumentals. The main similarities lie in the principle of economic activities based on the principles of solidarity and togatherness and the role of the state in the allocation of economic resources for economic prosperity and welfare of the whole people. Another important similarity is the presence of high concern towards the needy and neglected children through various economic policy instruments such as social security and social protection programs. Therefore, it is no longger relevant to polorize between the Indonesian economic constitution or Pancasila economic system and Islamic economic system. Because each is derived from an understanding of the Islamic teaching.

Keywords: constitution of Indonesian economy, UUD 1945, Islamic economic system, the role of the state

Abstrak. Analisis Kesesuaian Konstitusi Ekonomi Indonesia Terhadap Ekonomi Islam. Penelitian ini berusaha untuk melihat kesamaan antara kandungan konstitusi ekonomi Indonesia dengan ekonomi Islam. Secara garis besar konstitusi ekonomi Indonesia yang tertuan dalam UUD 1945 Pasal 33, 34, 23, 27 dan 28 memiliki kesamaan dengan sistem ekonomi Islam khususnya pada tataran nilai dasar, prinsip dasar dan instrumentalnya. Kesamaan dasarnya terletak pada asas kegiatan ekonominya yang didasarkan pada prinsip kekeluaragaan dan kebersamaan beserta peranan penting negara dalam pengalokasian sumber daya ekonomi untuk kemakmuran dan kesejahteraan bersama. Kesamaan penting lainnya adalah adanya kepedulian yang tinggi terhadap kaum fakir miskin dan anak-anak yang terlantar melalui instrumen-intrumen kebijakan ekonomi berupa jaminan dan perlindungan sosial. Olehnya, tidak perlu dilakukan pertentangan antara konstitusi ekonomi Indonesia atau ekonomi Pancasila dengan ekonomi Islam. Karena masing-masing merupakan turunan dari pemahaman terhadap agama Islam.
\end{abstract}

Kata kunci: konstitusi ekonomi Indonesia, UUD 1945, ekonomi Islam, peran negara.

\footnotetext{
${ }^{1}$ Naskah diterima: 12 Oktober 2013, direvisi: 12 Nopember 2013, disetujui: 20 Nopember 2013 Fakultas Ekonomi dan Bisnis UIN Syarif Hidayatullah Jakarta, e-mail: rama_clb_ku@yahoo.com ex.IDB Representative Indonesia, e-mail: makhlani@yahoo.com
} 


\section{PENDAHULUAN}

Corak sistem perekonomian suatu negara bisa saja sangat dipengaruhi oleh sistem ekonomi global seperti kapitalisme dan sosialisme yang hampir menjadi rujukan setiap negara dalam mendesain kebijakan ekonomi. Begitupula dengan Islam sebagai sistem kehidupan (way of life) suatu masyarakat memberikan pengaruh dalam desain sistem perekonomian suatu negara. Pedoman dan arah perekonomian suatu negara umumnya tertuan dalam undang-undang dasar atau konstitusi yang menjadi konsesus bersama negera tersebut.

Konstitusi harus dijadikan sebagai acuan substantif dalam setiap kebijakan yang diambil dalam proses pembangunan ekonomi. Kebijakan-kebijakan ekonomi yang diterapkan tidak seharusnya mengikut begitu saja terhadap arus perkembangan ekonomi yang terjadi, baik pada tataran nasional maupun global. Logika pembangunan ekonomi tidak semestinya dibangun semata atas pertimbangan pengalaman empiris di lapangan atau pun teori-teori dan kisah-kisah sukses di negara-negara lain yang dipandang layak dijadikan sebagai rujukan. Misalnya, Teori pembangunan seperti yang dikembangkan di Barat banyak dipengaruhi oleh karakteristik unik, masalah spesifik, nilai eksplisit dan implisit serta infrastruktur sosial-politik ekonomi Barat (Ahmad, 1997). Teori demikian jelas tidak bisa secara serta merta diaplikasikan di dunia Muslim yang memiliki nilai-nilai yang berbeda. Dengan demikian suatu teori yang cocok dan dapat diterima dalam suatu sistem masyarakat dengan pandangan hidup tertentu, belum tentu cocok bagi yang lain (An-Nabhani, 1996) (Ash Shadr, 2008).

Berdasarkan perspektif tersebut, teori ekonomi yang dipengaruhi oleh doktrin (sistem) suatu masyarakat tertentu belum tentu cocok dengan suatu masyarakat yang memiliki doktrin atau pandangan dunia (worldview) yang berbeda. Teori ekonomi pembangunan yang sukses di suatu daerah belum tentu cocok dan sukses di tempat lain, dikarenakan perbedaan pandangan hidup (Chapra, 2000). Alasan ini yang mendasari kenapa sistem sosialisme teruatama pola strategi pembangunan yang diadopsi bahkan dipaksakan pada negara-negara berkembang terutama negara-negara Muslim mengalami kegagalan bahkan berujung pada chaos dalam segala bidang (Matta, 1997). Kegagalan ini utamanya disebabkan oleh sistem atau doktrin yang terkandung dalam sosialisme memiliki perbedaan yang tajam dengan masyarakat Muslim yang sangat dipengaruhi oleh doktrin Islam. Sistem sosialisme yang diimpor ke dalam negara-negara muslim menghadapi akal yang berbeda dengan akal yang berbeda dengan akal yang menciptakannya, ditawarkan kepada masyarakat yang berbeda di mana sistem itu diterapkan - baik pada latar historisnya maupun struktur kesadarannya - dan disosialisasikan pada tanah dan waktu yang lain yang berbeda dengan tanah dan waktu darimana ia berasal. Maka yang terjadi kemudian adalah munculnya hasil yang berbeda (Matta, 1997).

Meskipun kenyataan saat ini, negara-negara dituntut untuk bergaul dengan sistem ekonomi global yang lebih cenderung kepada sistem ekonomi pasar kapitalisme yang mengedepankan liberalisasi perdagangan dan globalisasi ekonomi. Hegemoni sistem ekonomi global yang lebih cenderung dipengaruhi oleh sistem kapitalisme memberikan pengaruh yang besar dalam penyusunan dan pembuatan kebijakankebijakan ekonomi di negara-negara berkembang dan atau di negara-negara Muslim di mana Indonesia salah satu di dalamnya. Negara yang terbelakang dari berbagai aspek umumnya akan mengikut ke negara yang sudah relatif maju (Khaldun, 2000). Olehnya, untuk mencegah arus pengaruh sistem eksternal terhadap kebijakan ekonomi nasional maka seluruh kebijakan ekonomi yang diambil harus mengacu dan tidak boleh bertentangan dengan konstitusi ekonomi, UUD 1945 yang sudah menjadi konsensus 
bersama bangsa Indonesia yang disusun berdasarkan tujuan dan national interest yang ingin dicapai secara bersama sebagai bangsa Indonesia. Apalagi, UUD 1945 memuat dokumen ekonomi tentang ketentuan-ketentuan dalam bidang perekonomian yang merupakan cita-cita luhur yang diperjuangkan oleh para founding fathers dari Republik ini.

UUD 1945 sebagai konstitusi ekonomi mengatur mengenai pilihan-pilihan kebijakan ekonomi dan anutan prinsip-prinsip tertentu di bidang hak-hak ekonomi (economic rights). Konstitusi ekonomi memuat ketentuan mengenai perekonomian nasional. Banyak kalangan yang menilai bahwa konstitusi ekonomi Indonesia memiliki corak sesuai dengan nilai-nilai dan karakter budaya Indonesia yang sangat dipengaruhi oleh agama. Meskipun secara redaksional simbol-simbol agama tidak terlalu nampak dalam konstitusi ekonomi Indonesia tetapi nilai-nilai agama memiliki pengaruh yang kuat terhadap substansi yang dikandungnya.

Apalagi banyak kalangan yang menilai bahwa konstitusi ekonomi Indonesia sangat dipengaruhi oleh pemikiran Bung Hatta yang terutama tertuang dalam Pasal 33 dan 34 UUD 1945. Bung Hatta adalah merupakan tokoh nasional yang mempunyai kesempatan untuk mengenyam pendidikan di Barat sehingga tahu betul dinamika sistem ekonomi yang berkembang di Barat seperti sistem kapitalisme dan sosialisme. Beliau tahu betul kelemanan dari sistem kapitalisme dan sosialisme sehingga tidak cocok untuk diimplementasikan di Indonesia. Meskipun diakui bahwa pemikiran ekonomi Bung Hatta banyak dipengaruhi oleh paham sosialisme, tetapi sosialisme yang ingin dibangun di Indonesia adalah sosialisme yang berwatak agama atau sosialisme religius yang sesuia dengan agama masyarakat Indonesia secara umum. Bukan justru sosialisme yang anti agama atau ateis. Bahkan Bung Hatta sebenarnya memiliki pemikiran ekonomi yang sangat sesuai dengan pemikiran ekonomi Islam, tetapi pendekatan yang beliau lakukan lebih bersifat substansial dibandingkan dengan simbolistis (Abbas, 2008).

Kandungan konstitusi ekonomi yang ada dalam UUD 1945 bisa saja dipengaruhi oleh sistem ekonomi global di awal perumusannya. Seperti misalnya pengaruh prinsipprinsip sosialisme dalam penyusunan beberapa Pasal tentang ekonomi dalam UUD 1945. Akan tetapi banyak pula kalangan yang menilai bahwa Pasal-pasal ekonomi dalam UUD 1945 sangat dipengaruhi oleh nilai-nilai agama yang berkembang di tengah-tengah masyarakat Indonesia. Dalam artian, pemahaman dan kepercayaan agama khususnya Islam memiliki pengaruh kuat dalam filosofi dan prinsip dasar serta tujuan yang ingin dicapai yang terkandung dalam konstitusi ekonomi Indonesia.

Menurut Dawam Raharjo, konstitusi ekonomi Indonesia dilandasi oleh nilai-nilai yang terdapat dalam lima sila Pancasila. Pancasila, katanya, pada intinya adalah kombinasi tiga ideologi, yaitu Nasionalisme, Sosialisme dan Demokrasi, tetapi kesemuanya didasarkan pada Humanisme dan kepercayaan Monoteisme. Bahkan Bung Karno menyebut pancasila sebagai hasil gabungan dari tiga ideologi, yaitu Nasionalisme, Islamisme dan Komunisme yang biasa disebut sebagai Nasakom. Sementara Bung Hatta menyebut tiga sumber lain, yaitu Islam, Sosialisme dan budaya Indonesia.

Konstitusi ekonomi Indonesia memuat beberapa ketentuan-ketentuan ekonomi nasional seperti sistem kepemilikan sumber daya ekonomi, tujuan pembangunan ekonomi, pengelolaan sumber daya ekonomi, bentuk usaha ekonomi, sistem jaminan sosial, peran negara dalam pembangunan ekonomi, dan lainnya. Berdasarkan pada ketentuan-ketentuan pengaturan ekonomi yang terkandung dalam konstitusi ekonomi Indonesia maka perlu dilakukan analisis kesesuaian antara konsep ekonomi yang terkandung dalam konstitusi ekonomi Indonesia dengan konsep ekonomi dalam Islam. 
Sehingga akan ditemukan sejauh mana kesesuaian dan atau paralelitas antara konstitusi ekonomi Indonesia dengan konsep ekonomi Islam sehingga didapatkan kesimpulan yang utuh, komprehensif dan akurat tentang konstitusi ekonomi Indonesia ditinjau dari perspektif ekonomi Islam yang dapat dipertanggungjawabkan secara ilmiah.

\section{UUD 1945 SEBAGAI KONSTITUSI EKONOMI INDONESIA}

Pada umumnya, organisasi negara selalu memiliki naskah yang disebut sebagai konstitusi atau undang-undang dasar (UUD). Berlakunya suatu konstitusi sebagai hukum dasar yang mengikat didasarkan atas kekuasaan tertinggi atau prinsip kedaulatan yang dianut dalam suatu negara. Jika negara itu menganut paham kedaulatan rakyat, maka sumber legitimasi konstitusi itu adalah rakyat. Begitu pula jika yang berlaku adalah kedaulatan raja, maka raja yang menentukan berlaku tidaknya suatu konstitusi. Oleh karenanya, Indonesia sebagai negara yang menganut sistem demokrasi menempatkan rakyat sebagai penentu berlakunya suatu konstitusi.

UUD bukanlah undang-undang biasa. Konstitusi atau UUD dalam konteks Indonesia tidak ditetapkan oleh legislatif yang biasa, tetapi oleh badan yang lebih khusus dan lebih tinggi kedudukannya, yaitu Majelis Permusyawaratan Rakyat (MPR). Jika terdapat suatu undang-undang bertentangan dengan norma dasar yang terkandung di dalam UUD, maka UUD itulah yang berlaku.

Konstitusi menurut Asshiddiqie, adalah perjanjian, konsensus, atau kesepakatan tertinggi dalam kegiatan bernegara. Kesepakatan adalah hukum bagi siapa saja yang mengikatkan diri di dalamnya. Demikian pula konstitusi sebagai kesepakatan tertinggi, tentunya memiliki daya paksa yang juga bersifat tinggi. Konstitusi ekonomi adalah konstitusi yang mengatur mengenai pilihan-pilihan kebijakan ekonomi dan anutan prinsip-prinsip tertentu di bidang hak-hak ekonomi (Abbas, 2014).

Oleh sebab itu, para perumus kebijakan ekonomi harus menjadikan UUD 1945 sebagai hukum dan kebijakan yang tertinggi di bidang perekonomian. Setiap kebijakan ekonomi yang bertentangan dengan konstitusi ekonomi dapat dibatalkan dan dianggap tidak berlaku melalui mekanisme konstitusional, yaitu judical review di Mahkamah Konstitusi (MK).

UUD 1945 dikatakan sebagai konstitusi ekonomi karena mengatur ketentuan mengenai kebijakan ekonomi seperti yang tercantum dalam Pasal 33 UUD 1945. Pasal 33 menentukan, (1) Perekonomian disusun sebagai usaha bersama berdasarkan atas asas kekeluargaan; (2) Bumi dan air dan kekayaan yang terkandung didalamnya dikuasai oleh negara dan dipergunakan untuk sebesar-besarnya kemakmuran rakyat. Hasil amandemen paska reformasi atas UUD 1945, Bab XIV yang semula hanya, "Kesejahteraan Sosial" direvisi menjadi "Perekonomian Nasional dan Kesejahteraan Sosial" dimana memuat dua Pasal, yaitu Pasal 33 dan Pasal 34 beserta penyempurnaan ayat-ayatnya.

Pasal-pasal lainnya yang berkaitan dengan ekonomi yang ada dalam UUD 1945 adalah Pasal 23 mengenai keuangan negara dan hal-hal yang terkait, Pasal 27 Ayat 2 tentang pekerjaan dan peghidupan yang layak bagi kemanusiaan, dan Pasal 28 tentang hak asasi manusia. Bahkan Alinea IV Pembukaan UUD 1945 yang berisi prinsip-prinsip dasar Pancasila dan Tujuan Bernegara secara tidak langsung juga mengandung gagasan mengenai kesejahteraan sosial dan ekonomi.

Jika dilihat dari segi sistem ekonomi, ekonomi Indonesia tidak bisa sepenuhnya dikatakan menganut sistem kapitalisme ataupun sosialisme ataupun gabungan dari kedua dari sistem tersebut (mixed economy). Misalnya dari segi kepemilikan sumber daya ekonomi atau faktor-faktor produksi, tak terdapat alasan untuk mengatakan bahwa 
sistem ekonomi Indonesia adalah kapitalisme. Sama halnya, tidak terdapat argumentasi yang cukup untuk mengatakan, bahwa kita menganut sistem ekonomi sosialis. Indonesia mengakui kepemilikan individual atas faktor-faktor produksi, kecuali untuk sumber daya-sumber daya yang menguasai hidup orang banyak, dikuasai oleh negara (Tambunan, 2011). Hal ini secara tegas diatur oleh Pasal 33 UUD 1945. Jadi secara konstitusional, sistem ekonomi Indonesia tidak mengikut secara absolut terhadap sistem ekonomi kapitalisme maupun sosialisme. Sistem ekonomi Indonesia, menurut Mubyarto (1987), adalah sistem ekonomi Pancasila yang didasarkan pada lima sila yang dimilikinya. Akan tetapi jika dilihat dari nilai-nilai dan sistem kepemilikan yang dianutnya, sistem ekonomi Indonesia memiliki kesamaan yang besar dengan sistem ekonomi Islam.

\section{SISTEM EKONOMI INDONESIA}

Pengertian tentang sistem ekonomi sangat beragam. Sanusi (2010) menjelaskan sistem ekonomi merupakan suatu organisasi yang terdiri atas sejumlah lembaga dan pranata (ekonomi, sosial-politik, ide-ide) yang saling mempengaruhi satu dengan yang lainnya dan ditujukan ke arah pemecahan problem-problem serta produksi-distribusi konsumsi yang merupakan problem dasar setiap perekonomian. Dengan kata lain, sistem ekonomi dapat diartikan sebagai suatu totalitas terpadu yang terdiri dari atas unsur-unsur yang saling berhubungan, saling terkait, saling mempengaruhi, dan saling tergantung untuk mencapai tujuan bersama.

Selanjutnya, Dumairy (2011) mengartikan sistem ekonomi adalah suatu sistem yang mengatur serta menjalin hubungan ekonomi antarmanusia dengan seperangkat kelembagaan dalam suatu tatanan kehidupan. Sebuah sistem ekonomi terdiri atas unsur-unsur manusia sebagai subjek; barang-barang ekonomi sebagai objek; serta seperangkat kelembagaan yang mengatur dan menjalinnya dalam kegiatan perekonomian. Perangkat kelembagaan dimaksud meliputi lembaga-lembaga ekonomi (formal maupun informal); cara kerja; mekanisme hubungan; hukum dan peraturanperaturan perekonomian; serta kaidah dan norma-norma lain (tertulis maupun tidak tertulis); yang dipilih atau diterima atau ditetapkan oleh masyarakat di tempat tatanan kehidupan yang bersangkutan berlangsung. Jadi dalam perangkat kelembagaan ini termasuk juga kebiasaan, perilaku, dan etika masyarakat; sebagaimana mereka terapkan dalam berbagai aktivitas yang berkenaan denga pemanfaatan sumber daya bagi pemenuhan kebutuhan. Berdasarkan definisi ini menunjukkan bahwa mengkaji sistem ekonomi berarti meliputi tentang pelaku-pelaku ekonomi, lembaga-lembaga ekonomi, mekanisme, aturan-aturan dan doktrin atau paradigma ekonomi yang dianut.

Definisi serupa juga dikemukan oleh Grossman (1995) yaitu sistem ekonomi adalah sekumpulan komponen atau unsur terdiri atas unit dan agen ekonomi serta lembaga (institusi) ekonomi, yang bukan saja saling berhubungan dan berinteraksi melainkan juga sampai tingkat tetentu saling menopang dan mempengaruhi.

Sementara itu, Triono (2011) menganggap bahwa sistem ekonomi berkaitan dengan pandangan, keyakinan, kepercayaan ataupun ideologi tertentu, khususnya terhadap alokasi sumber daya ekonomi yang ada di bumi ini. Sehingga sistem ekonomi akan menyangkut pandangan terhadap kepemilikan, pemanfaatan, maupun distribusi sumber daya ekonomi. Sehingga sistem ekonomi itu tidak netral dan bersifat subjektif karena dipengaruhi oleh pandangan-pandangan hidup atau paradigma tertentu di mana sistem ekonomi itu diterapkan. Konsekuesinya, berdasarkan definisi ini, sistem ekonomi yang diterapkan dan dianut dalam suatu perekonomian negara sangat memungkinkan berbeda dengan sistem ekonomi yang diterapkan di tempat atau negara lain, tergantung pada pandangan dan paradigma yang dianutnya terutama dalam hal kepemilikan, 
pemanfaatan dan distribusi sumber daya ekonomi yang dimiliki dalam suatu perekonomian.

Kahf (1999) mendefinisikan sistem ekonomi sebagai seperangkat prinsip-prinsip yang merupakan kerangka organisasi kegiatan ekonomi. Sehingga sistem ekonomi tertentu tersusun dari seperangkat nilai-nilai yang dapat membangun kerangka organisasi kegiatan ekonomi menurut kerangka referensi tertentu. Perangka nilai-nilai ini di satu pihak akan berdasarkan pandangan filsafat tentang kegiatan ekonomi, dan dipihak lain interaksi nilai-nilai ini membentuk perangkat nilai dasar dan nilai instrumental bagi kegiatan ekonomi yang dikehendaki oleh sistem.

Dalam literatur ekonomi dan bahkan tataran penerapan perekonomian, dikenal dua sistem ekonomi yang sering diperbincangkan dan mempengaruhi suatu perekonomian, yaitu kapitalisme pasar dan sosialisme terpimpin. Dua sistem ekonomi ini sebenarnya saling terkait. Sistem ekonomi sosialisme muncul atas kritik terhadap sistem kapitalisme yang tidak bisa mewujudkan kesejahteraan bagi berbagai lapisan masyarakat. Inti dari sistem ekonomi kapitalisme adalah pemecahan masalah ekonomi yang meliputi produksi, konsumsi dan distribusi melalui mekanisme pasar bebas demi tercapainya kesejahteraan masyarakat secara bersama. Sementara ekonomi sosialisme meyakini bahwa penghapusan kepemilikan individu terhadap aset-aset produksi adalah solusi untuk menyelesaikan problem ekonomi yang dihadapi oleh manusia dan merupakan pendekatan yang paling ampuh untuk mewujudkan kesejahetaraan yang merata.

Kehadiran dua sistem ekonomi itu, berkontribusi dalam menciptakan polarisasi hegemonis sistem ekonomi dalam tataran global. Kedua sistem ekonomi ini saling berusaha mencari pengikut (follower) dan situasi ini memicu munculnya konflik seperti yang pernah terjadi pada perang dingin (cold war) antara Amerika Serikat (AS) sebagai pengusung utama sistem ekonomi Kapitalisme dengan Uni Soviet sebagai pengusung sistem Sosialisme. Kedua sistem ekonomi itu menghegemoni khususnya di negaranegara berkembang. Akhirnya banyak negara-negara berkembang meyakini bahwa untuk mencapai kemajuan ekonomi caranya adalah dengan mengadopsi salah satu sistem ekonomi tersebut, sistem kapitalisme atau sistem sosialisme.

Akan tetapi dalam peraktiknya, sistem ekonomi yang dijalankan oleh negaranegara di dunia saat ini tidak sepenuhnya seperti sistem Kapitalisme atau sistem Sosialisme yang berada pada titik ekstrim sebagaimana dicetuskan oleh masing-masing penggagasnya yaitu Adam Smith dan Karl Max. Justru sistem perekonomian yang diterapkan di berbagai negara saat ini berada di sepanjang spektrum dua sistem tersebut. Apa yang disebut Kapitalisme dan Sosialisme memiliki banyak bentuk variannya dalam tataran prakteknya. Akan tetapi perlu diakui kedua sistem tersebut sangat mempengaruhi sistem ekonomi yang berlaku di dunia ini dengan penyesuaian sesuai dengan kepentingan pragmatis negara yang mengadopsinya. Kedua sistem tersebut dalam tataran implementasinya juga disesuaikan dengan nilai-nilai dan normanorma serta agama yang berlaku dalam suatu masyarakat.

Selain kedua sistem tersebut, dalam perekonomian modern juga dikenal sistem ekonomi campuran (mixed economy) yaitu sistem yang mengandung beberapa elemen dari sistem ekonomi kapitalisme dan sistem ekonomi sosialisme. Sebagaimana dikemukan sebelumnya, tidak ada perekonomian yang ada saat ini yang mengadopsi sepenuhnya sistem ekonomi sosialis atau kapitalis. Yang berlaku justru campuran antara kedua ekstrim sistem ekonomi tersebut, dengan berbagai varian kadar dominasinya. 
Deklarasi Indonesia sebagai negara merdeka terjadi bersamaan dengan puncak perseturuan antara sistem ekonomi kapitalisme yang diwakili oleh Amerika Serikat yang kemudian membuat sekutu dengan sebutan Blok Barat dan sistem ekonomi sosialisme yang dikomandoi oleh Uni Soviet dengan Blok Timurnya. Pertanyaannya kemudian adalah apakah pembentukan sistem ekonomi Indonesia seteleh proklamasi kemerdekaannya (17 Agustus 1945) dipengaruhi oleh dua arus sistem tersebut atau dua Blok politik tersebut?

Sebagaimana diketahui setelah kemerdekaan Republik Indonesia (RI), Presiden Pertama RI, Soekarno justru memploklamirkan Blok Baru bernama Gerakan Non-Blok yang tidak berafiliasi dengan Blok Barat maupun Blok Timur yang lagi berebutan mencari pengaruh dan sekutu pada saat itu. Pandangan politik ini sebenarnya juga berpengaruh pada sistem ekonomi yang dianut Indonesia yang tidak menganut sitem ekonomi kapitalis ataupun sistem ekonomi sosialis sepenuhnya.

Sistem ekonomi apa yang diterapkan di Indonesia, Kapitalisme, sosilisme, atau gabungan (mixed) dari kedua sistem tersebut? Untuk menjawab pertanyaan ini, Dumairy (1996) menegaskan sebagai berikut, "Ditinjau berdasarkan sistem kepemilikan sumber daya ekonomi atau faktor-faktor produksi, tak terdapat alasan untuk menyatakan bahwa sistem ekonomi kita adalah kapitalisme. Sama halnya, tak pula cukup argumentasi untuk mengatakan, bahwa kita menganut sistem ekonomi sosialis. Indonesia mengakui pemilikan individual atas faktor-faktor produksi, kecuali untuk diatur dengan tegas oleh Pasal 33 UUD 1945. Jadi, secara konstitusional, sistem ekonomi Indonesia bukan kapitalisme dan bukan pula sosialisme."

Untuk memahami sistem ekonomi apa yang diterapkan di Indonesia paling tidak secara konstitusional maka perlu memahami terlebih dahulu ideologi yang dianut oleh Indonesia. Sistem ekonomi atau perekonomian Indonesia tidak terlepas dari prinsipprinsip dasar dari pembentukan negara Republik Indonesia yang tercantum dalam Pancasila dan Undang-Undangan Dasar (UUD) 1945.

\section{SISTEM EKONOMI PANCASILA}

\section{Pancasila dan Agama}

Pancasila sebagai ideologi Indonesia sebenarnya dalam proses pembentukannya sangat dipengaruhi oleh ajaran-ajaran Islam. Pancasila sebagaimana dituliskan oleh Adian Husaini (2010) adalah merupakan hasil karya bersama, bukanlah rumusan semata seorang Bung Karno sendirian. Pancasila adalah hasil kesepakatan tokoh-tokoh Islam yang memiliki berbagai aspirasi ideologis, termasuk tokoh-tokoh Islam yang tergabung dalam Panitia Sembilan di BPUPK, yaitu KH. Wahid Hasyim, Haji Agus Salim, Abikoesno Tjokrosoejoso dan Abdul Kahar Muzakkir. Salah satu bukti utama jikalau Pancasila yang kemudia menjadi landasan Ideologi bangsa Indonesia begitupula dalam sistem ekonominya sangat dipengaruhi oleh ajaran Islam atau pandangan Islam (Islamic worldview) adalah adanya rumusan tujuh kata pada sila pertama, yaitu "Ketuhanan, dengan kewajiban menjalankan syariah Islam bagi pemeluk-pemeluknya" yang kemudian dikenal sebagai rumusan Piagam Pancasila vesi Piagam Jakarta (Pembukaan UUD 1945). Akan tetapi karena suatu hal, sila pertama Pancasila ini diganti menjadi "Ketuhanan Yang Maha Esa". Sila pertama ini menurut Adian Husaini adalah representasi dari ajaran tauhid dalam agama Islam. Bukti-bukti lainnya bahwa Pancasila sangat dipengaruhi oleh ajaran Islam adalah bisa dilihat dari sila-sila lainnya. Karim (2004) mengungkapkan penilaian yang sama. Ia menganggap bahwa nilai-nilai universal Islam secara eksplisit menjiawai muatan Pancasila yang berprinsip ketuhanan, kemanusiaan, persatuan, permusyawaratan, dan keadilan. Hal ini sejalan dengan Islam yang menekankan persamaan, persaudaraan, permusyawaratan, keadilan dan 
ketuhanan. Oleh karenanya, rumusan dan penafsiran sila-sila Pancasila terutama sila pertama jelas tidak bisa dipisahkan dari konteks sejarah munculnya rumusan tersebut.

Harus diakui bahwa pada masa lalu ada mutual understanding antara Islam sebagai agama dan Pancasila sebagai ideologi. Kesalahpahaman itu lebih banyak pada berbagai kepentingan politik daripada dalam substansinya; atau lebih dikarenakan oleh ketidakjelasan paradigma dan cara pandang. Substansinya keduanya jelas berbeda. Islam adalah agama, sedangkan Pancasila adalah ideologi. Esensi (hakekat) Islam dan Pancasila tidak bertentangan, namun kenyataan eksistensinya (sejarahnya) dapat saja dipertentangkan terutama untuk melayani kepentingan-kepentingan kelompok sosial (Karim, 2004). Contohnya misalnya sebagaimana yang diungkapkan oleh Adnan Buyung Nasution sebagaimana dikutip oleh Adian Husaini terjadinya polemik dan komprontasi ide antara Islam dan Pancasila dalam sejarah di Indonesia adalah akibat dikembangkannnya konsep Pancasila sebagai doktrin atau pandangan hidup (worldview) yang kompleks dan khas, sehingga berbenturan dengan pandangan dunia lain, seperti Islam. Bahkan lebih jauh rezim Orde Baru menjadikan Pancasila sebagai landasan amal dan moral dimana wilayah ini sebenarnya menjadi wilayah agama. Pancasila berusaha ditafsirkan oleh penguasa melampaui kewenangannya bahkan masuk ke kewenangan agama. Justru Pancasila sebagai landasan negara jika dilihat dalam konteks sejarahnya tidak bertentangan dengan ajaran agama khususnya agama Islam, bahkan nilai-nilai universalnya terinspirasi oleh nilai-nilai universal Islam sebagaimana tercantum dalam sila-sila Pancasila.

Pancasila sebagai ideologi sebenarnya merupakan objektivikasi dari Islam. Objektivikasi adalah penterjemahan nilai-nilai internal ke dalam kategori-kategori objektif. Atau dengan kata lain, objektivikasi adalah merupakan konkritisasi dari keyakinan internal. Hal ini berarti unsur-unsur objektif agama ada dalam pancasila.

\section{Sistem Ekonomi Pancasila}

Istilah 'ekonomi pancasila', menurut Dawam Rahardjo, dipopulerkan oleh Emil Salim dalam salah satu artikelnya pada tahun 1976. Menurut beliau ekonomi pancasila merupakan suatu konsep kebijakan ekonomi, setelah mengalami pergerakan seperti bandul jam dari kiri ke kanan, hingga mencapai titik keseimbangan. Ke kanan artinya bebas mengikuti aturan pasar, sedangkan ke kiri artinya mengalami intervensi negara dalam bentuk perencanaan memusat. Ekonomi pancasila juga dapat diartikan sebagai sistem ekonomi pasar dengan pengendalian pemerintah atau "ekonomi pasar terkendali". Mungkin istilah lain yang lebih mendekati dan populer dengan pengertian 'ekonomi pancasila' adalah 'sistem ekonomi campuran' (mixed economy), maksudnya campuran antara sistem akpitalisme dan sosialisme atau 'sistem ekonomi jalan tengah'.

Pancasila menurut Soekarno adalah merupakan hasil kombinasi ideologi 'nasionalisme', 'islamisme', dan 'komunisme'. Sedangkan Bung Hatta menyebutnya sebagai kombinasi dari 'Islam', 'sosialisme', dan 'budaya Indonesia'. Dengan demikian, jika ekonomi pancasila dirumuskan sebagai 'ekonomi yang mendasarkan dari nilai-nilai pancasila', maka ekonomi pancasila sebenarnya adalah sebuah sistem ekonomi campuran. Ekonomi pancasila juga biasa disebut sebagai 'ekonomi kerakyatan', sebagaimana dijelaskan oleh Mubyarto (1987) bahwa praktek ekonomi pancasila atau ekonomi pancasila in action, dengan mudah dapat dijumpai dan dikenali di mana-mana di seluruh Indonesia. praktek ekonomi ini seringpula disebut 'ekonomi rakyat' yang bersifat moralistik, demokratik dan mandiri. Dengan gambaran dan pembahasan itu sering ekonomi pancasila diidentikkan dengan ekonomi rakyat. Perekonomian rakyat pada dasarnya adalah perekonomian pasar yang didasarkan pada sistem kepemilikan individu dan kolektif. 
Ekonomi pancasila disebut juga sebagai ekonomi yang berasaskan kekeluargaan, kegotong-royongan dan kerjasama. Ini adalah nilai-nilai tradisional yang bersumber dari budaya Indonesia, yang bisa saja sangat dipengaruhi oleh nilai-nilai agama yang dianut oleh masyarakat Indonesia. Asas kekeluargaan ini, yang berdasarkan pada solidaritas mekanis, menurut Dawam Rahardjo, telah ditransformasikan menjadi solidaritas fungsional, dengan nilai-nilai individualitas dalam lembaga koperasi. Jika ekonomi pancasila didasarkan pada Pasal 33 UUD 1945 yang menyebutkan bahwa cabang-cabang penting kebutuhan rakyat dikuasai oleh negara, sehingga melahirkan BUMN. Jika ini menjadi ciri ekonomi pancasila, maka ekonomi pancasila mengikuti model negara kesejahteraaan (welfare state) yang umumnya berkembang di negara-negara Eropa.

Mubyarto (1987) mendefinisikan ekonomi pancasila sebagai sistem ekonomi, atau sistem perekonomian yang dijiwai oleh ideologi pancasila, yaitu ekonomi yang dijiwai oleh usaha berdasarkan pada asas kekeluargaan dan kegotongroyongan nasional. Mengenai ekonomi pancasila, Mubyarto mengemukakan lima karakter utamanya. Kelima ciri tersebut masih harus dikembangkan, ditumbuhkan dan diperjuangkan dalam sistem perekonomian Indonesia. Kelima ciri ekonomi pancasila tersebut diserap dari UUD 1945 dan dari keseluruhan jiwa pancasila itu sendiri. Kelimanya adalah sebagai berikut: Pertama, dalam sistem ekonomi pancasila, koperasi merupakan soko guru perekonomian. Kedua, perekonomian digerakkan oleh ransangan-ransangan ekonomi, sosial dan moral. Ketiga, egalitarianisme yaitu bahwa kemerataan sosial mengandaikan terpenuhinya semangat kekeluargaan, saling menyayanging sesama manusia dan solidaritas persaudaraan. Keempat, bagian ini berhubungan dengan sila ketiga "Persatuan Indonesia". Kelima, pengandalan pada sistem desentralisasi dalam pelaksanaan kegiatan-kegiatan ekonomi, diimbangi dengan perencanaan yang kuat sebagai pemberi arah bagi perkembangan ekonomi.

Sebagian menilai bahwa ekonomi pancasila sangat dipengaruhi oleh nilai-nilai agama, meskipun menggunakan bahasa yang universal tanpa simbol-simbol agama di dalamnya. Ekonomi pancasila adalah ekonomi yang didasarkan pada monoteisme dan humanisme. Prinsip dalam sila pertama; Ketuhanan Yang Maha Esa dan sila kelima; keadilan sosial bagi seluruh rakyat Indonesia. Merupakan hasil pemikiran manusia Indonesia yang berakar dari prinsip-prinsip nilai agama (tauhid), demikian pula dengan humanisme, berakar pada nilai-nilai agama.

Namun demikian, kajian terhadap ekonomi pancasila terutama dari segi ontologi, epistimologi dan aksiologi masih jarang dilakukan. Dari segi ontologinya misalnya, apa itu ekonomi pancasila secara teoritis-konseptual maupun empirisnya? Selanjutnya adalah masalah epistimologis yang menyangkut pemahamam dan praktek pengembangan ekonomi pancasila. Sementara dari segi epistimologi juga masih belum bayak dikaji. Masalah ini membutuhkan kajian teori dan empiris guna mengetahui tujuan dan hasil akhir proses ekonomi pancasila.

\section{KONSTITUSI EKONOMI INDONESIA BERDASARKAN UUD 1945}

Dalam pembukaan UUD 1945 secara jelas dikemukakan kembali istilah "Ketuhanan Yang Maha Esa". Ini menandakan bahwa konstitusi negara Republik Indonesia didasarkan pada agama (tauhid). Artinya, penafsiran dari lima sila dari pancasila tidak bisa dipisahkan dari cara pandang agama (worldview). Hal ini secara jelas termaktub dalam pasar 29 ayat 2: "Negara berdasarkan atas Ketuhanan Yang Maha Esa". Sebagaimana dijelaskan sebelumnya kalimat tersebut merujuk pada ajaran tauhid dalam agama Islam.

Ketentuan-ketentuan dasar konsttusional mengenani kehidupan ekonomi berdasarkan Pancasila dan UUD 1945 antara lain tercermin dalam pasal-pasal berikut: 
23, 33 dan 34 UUD 1945. Secara rinci, pasal 33 UUD 1945 menetapkan tiga hal, yaitu: Pertama, 'Perekonomian disusun sebagai usaha bersama berdasarkan atas asas kekeluargaan'. Menurut Gunadi (1981), pernyataan ini adalah pernyataan asasi dan monumental bagi sistem perekonomian Indonesia menurut Pancasila dan UUD 1945. Dari pernyataan ini menunjukkan bahwa perekonomian dilakukan secara bersama yang menggambarkan adalanya kehidupan sosial yang harmonis. Penyebutan asas kekeluargaan menunjukkan bahwa hasil produksi yang diperoleh dari pengembangan perekonomian itu dipergunakan untuk kesejahteraanb bersama/sosial. Azas kekeluargaan menurut Asshiddiqie (2010) menunjukkan bahwa perekonomian Indonesia tidak didasari pada persaingan yang sengit tetapi lebih mengutamakan kerjasama. Istilah 'disusun' menurut Sri Edi Swasono menunjukkan bahwa perekonomian harus 'disusun' tidak dibiarkan 'tersusun' sendiri melalui mekanisme pasar ala competitive economics. Pada pasal ini mengindikasikan perlunya keterlibatan negara dalam perekonomian. Sementara itu, Gunadi (1981) menganggap bahwa Pasal 33 ayat 1 ini adalah merupakan cita-cita perekonomian yang dipandang sebagai jalan terbaik untuk membela ekonomi yang lemah.

Kedua, 'Cabang-cabang produksi yang penting bagi negara dan menguasai hajat hidup orang banyak dikuasai oleh negara'. Ketentuan dalam pasal ini mengarah kepada sistem sosial dalam arti hasil produksi yang penting jangan sampai dikuasai oleh orang per orang, akan tetapi oleh negara dalam arti agar pendistribusiannya dapat dilaksanakan secara merata. Ini menunjukkan bahwa pemerintah sendiri yang menjadi pemilik dan sekaligus pelaku usaha dengan bentuk organisasi pengelolaannya di lapangan.

Ketiga, Bumi dan Air dan Kekayaan alam yang terkandung di dalamnya dikuasai oleh negara dan dipergunkan untuk sebesar-besarnya kemakmuran rakyat. Pasal ini menunjukkan bahwa semua kekayaan yang terkandung di dalam bumi, air, dan alam tidak dikuasai oleh perseorangan atau suatu kelompok, melainkan dikuasai oleh negara dan dipergunakan untuk sebesar-besarnya untuk kesejahteraan rakyat. Ayat ini memperjelas bahwa sistem ekonomi Indonesia menganut sistem kepemilikan individu, umum dan negara.

Sedangkan pasal 27 ayat 2 menerapkan bahwa setiap warga negara (WNI) berhak atas pekerjaan serta penghidupan yang layak; dan pasal 34 menetapkan bahwa kaum masyarakat miskin dan anak-anak yang terlantar dipelihara negara. Pasal ini melindungi warga negara yang karena keterbatasannya tidak mampu mencari sumber penghidupan atau mereka yang mampu memperoleh pekerjaan tetapi hasilnya tidak mencukupi. Begitupula dengan anak-anak terlantar, fakir miskin, patut mendapatkan perlindungan dan santunan dari pemerintah agar mereka dapat menikmati hasil pembangunan ekonomi Indonesia. Ini menunjukkan bahwa negara punya peranan besar dalam menciptakan keadilan sosial bagi seluruh rakyatnya.

Oleh karena itu dapat disimpulkan bahwa sistem ekonomi Indonesia tercermin dalam Pancasila dan UUD 1945. Bahkan banyak kalangan seperti misalnya Mubyarto, Muhammad Hatta, Dawam Rahardjo, Sri-Edi Swasono, dll mengatakan bahwa sistem ekonomi Indonesia adalah sistem ekonomi Pancasila. Menurut Dawam Rahardjo (1997) ekonomi Pancasila dapat disebut sebagai sistem ekonomi Pancasila. Akan tetapi ia membedakan antara sistem ekonomi pancasila dengan sistem ekonomi Indonenesia. Ekonomi pancasila yang dia maksud adalah suatu konsep yang sifatnya teoritis. Sementara sistem ekonomi Indonesia adalah sistem ekonomi nasional berdasarkan pancasila dan UUD 1945. Artinya sistem ini adalah konsep operasional sistem ekonomi yang berlaku di Indonesia. Keduanya tidak identik atau sama, bahkan sistem ekonomi 
Indonesia yang berlaku bisa saja berbeda bahkan bertentangan dengan sistem ekonomi pancasila. Bahkan lebih jauh Dawam Rahardjo setelah melihat persamaan dan kesamaan prinsip-prinsip ekonomi yang ada dalam sistem ekonomi Pancasila mengambil kesimpulan bahwa sistem ekonomi pancasila adalah sistem ekonomi Islam dalam konteks Indonesia. Hal ini sejalan dengan yang dikemukan oleh Abdul Karim sebelumnya bahwa pancasila pada hakekatnya adalah hasil objektifikasi dari ajaranajaran yang dianut oleh masyarakat Indonesia.

Sementara itu, Sri-Edi Swasono (2012) mengatakan bahwa ekonomi pancasila bisa dikatakan seiring dan selaras dengan apa yang sering diungkapkan oleh sebagai ekonomi syariah/Islam, keduanya compatible meskipun tidak sepenuhnya substitutable, dengan kata lain ekonomi pancasila sudah sangat Islami.

Namun dalam perakteknya, sistem ekonomi Indonesia dalam praktek penerapannya dalam beberapa dekade belakangan ini sejak era orde baru cenderung kapitalis dan cenderung bersifat sosialis di era Soekarno. Ini jelas bertentangan dengan konstitusi negara yang tidak menganut sistem kapitalis dan sosialisme. Ini mengindikasikan bahwa sistem ekonomi Indonesia selalu berjalan sesuai dengan selera dan kepentingan politik para penguasa yang sedang berkuasa. Padahal jika dilihat secara historis dan isi dari konstitusi Republik Indonesia dimana sistem ekonominya dilandasi oleh Pancasila dan UUD 1945 justru sangat sejalan dengan ajaran-ajaran Islam khususnya dalam bidang ekonomi Islamnya.

Akan tetapi perjalanan bangsa Indonesia dalam membangun ekonomi berdasarkan pada landasan konstitusinya (pancasila dan UUD 1945) cenderung terbawa arus pada pola pembangunan ala sistem sosialisme dan sistem kapitalisme justru menjadi warisan kekayaan atau aset bangsa Indonesia dalam menemukan format pembangunan ekonomi yang sejalan dengan kepribadian bangsa Indonesia. Warisan pola pembangunan ini tentunya juga akan memperkaya konsep ekonomi Islam yang sangat normatif untuk melakukan eksperimentasi dalam mencari bentuknya.

Hal ini sejalan dengan apa yang diungkapkan oleh Dawam Rahadjo (1997) bahwa penafsiaran dan pengembangan ekonomi Islam ternyata lebih kaya dan yang lebih penting menjadi relevan jika didasarkan pada pengalaman-pengalaman konkrit pembangunan, baik di negara-negara Muslim maupun di Indonesia. Dalam mencari hukum-hukum ekonomi sejalan dengan asas tauhid, pengalaman-pengalaman praktik nerupakan bahan bagi validasi hukum-hukum ekonomi Islam. Dengan pendekatan ini, maka perlu mememulai kerja praktik pembangunan, berdasarkan teori dan konsepkonsep yang garis besar saja. Dewasa ini pengalaman praktik pembangunan di Indonesia telah dipakai sebagai bahan untuk mengembangkan ekonomi Islam lebih lanjut dan relevan.

\section{UUD 1945 DAN EKONOMI ISLAM}

Pembukaan UUD 1945 memuat empat tujuan negara Indonesia yaitu, “.... Untuk membentuk suatu pemerintahan Negara Indonesia yang melindungi segenap bangsa Indonesia dan seluruh tumpah darah Indonesia dan untuk memajukan kesejahteraan umum, mencerdaskan kehidupan bangsa, dan ikut melaksanakan ketertiban dunia yang berdasarkan kemerdekaan, perdamaian abad dan keadilan sosial,...". Untuk mencapai keempat tujuan tersebut, terutama untuk memajukan kesejahteraan umum dan mencerdaskan kehidupan bangsa, diadakan pengaturan-pengaturan mengenai anggaran pendapatan dan belanja negara ( Bab VIII dan Bab VIIIA); mengenai hak-hak asasi manusia dan warga negara di bidang ekonomi dan kesejahteraan rakyat (Bab XA); didukung oleh bab tentang pendidikan bagi warga negara Indonesia sebagai subjek 
pembangunan kesejahteraan tersebut; dan (Bab XIII); dan khusus mengenai kebijakan perekonomian nasional dan kesejahteraan sosial diatur dalam Bab XIV.

Hasil amandemen UUD 1945 pasca reformasi, Pasal-pasal perekonomian dirumuskan dalam bab tersendiri, yaitu Bab XIV yang semula berjudul "Kesejahteraan Sosial" diamandemen menjadi "Perekonomian Nasional dan Kesejahteraan Sosial". Adapun kandungan pasalnya terdiri dari dua pasal, yaitu Pasal 33 yang terdiri atas 5 ayat dan Pasal 34 yang terdiri atas 4 ayat.

\section{Pasal 33 UUD 1945}

Pasal 33 UUD 1945 terdiri dari 5 ayat, tiga ayat pertama adalah merupakan warisan dari the founding leaders. Sementara dua sisanya merupakan hasil amandemen pada tahun 2002. Adapun ayat yang terkandung dalam Pasal 33 UUD 1945 adalah sebagai berikut:

(1) Perekonomian disusun sebagai usaha bersama berdasarkan atas asas kekeluargaan;

(2) Cabang-cabang produksi yang penting bagi negara dan yang menguasai hajat hidup orang banyak dikuasai oleh negara;

(3) Bumi dan air dan kekayaan alam yang terkandung di dalamnya dikuasai oleh Negara dan digunakan untuk sebesar-besar kemamkmuran rakyat;

(4) Perekonomian nasional diselenggarakan berdasarkan atas demokrasi ekonomi dengan prinsip kebersamaan, efisiensi-berkeadilan, berkelanjutan, berwawasan lingkungan, kemandirian, serta dengan menjaga keseimbangan kemajuan dan kesatuan ekonomi nasional;

(5) Ketentuan lebih lanjut mengenai pelaksanaan pasal ini diatur dalam undangundang.

Pasal 33 Ayat (1) UUD 1945 berbunyi, "Perekonomian disusun sebagai usaha bersama berdasarkan atas asas kekeluargaan". Sri-Edi Swasono menginterpretasikan kata 'disusun' sebagai bentuk imperatif yang berarti harus disusun dan tidak boleh dibiarkan tersusun dengan sendirinya. Artinya, perekonomian harus disusun dan tidak boleh dibiarkan tersusun sendiri melalui mekanisme pasar bebas. Karena jika perekonomian dibiarkan tersusun sendiri seperti dalam aliran competitive economics, maka akan berdampak pada persaingan yang tidak adil. Pemodal yang besar punya peluang untuk menguasai dan mengeksploitasi para pemodal kecil (Lihat QS Al-Hasy: 7). Semangat pengaturan ini menempatkan pemerintah/negara sebagai salah satu elemen penting dalam perekonomian. Dalam perspektif ekonomi Islam, negara melalui dengan lembaga hisbah-nya punya otoritas untuk melindungi kepentingan orang-orang yang lemah supaya terjadi keseimbangan dalam perekonomian.

Penafsiran yang agak berbeda terhadap kata "disusun" dikemukakan oleh Asshiddiqie (2010). Menurutnya, kata 'disusun' berarti susunan kebijakan yang sistematis dan menyeluruh, mulai dari susunan tingkat nasional sampai ke susunan di daerah-daerah provinsi dan kabupaten/kota di seluruh Indonesia. Susunan perekonomian merupakan suatu bentuk "Usaha bersama" atas dasar "asas kekeluargaan". Usaha bersama atas dasar kekeluargaan dapat dilihat dari tiga aspek, yaitu pengertian mikro, pengertian makro dan usaha bersama sebagai prinsip atau sebagai jiwa.

Pengertian mikro dari usaha bersama dapat dikaitkan pada bentuk usahanya yaitu koperasi sebagai bentuk usaha bersama. Pengertian ini tidak bisa sepenuhnya digunakan karena susunan perekonomian Indonesia tidak sepenuhnya berbentuk koperasi. Sementara pengertian makro diartikan sebagai usaha bersama seluruh rakyat Indonesia di bidang perekonomian. Pengertian kebersamaan tidak hanya berkaitan 
dengan konsep bentuk usaha, tetapi lebih jauh lagi berkaitan dengan konsep pelaku ekonomi yang tidak hanya dijalankan oleh bangun perusahaan. Pengertian pelaku ekonomi tidak hanya terbatas pada BUMN, perusahaan swasta dan koperasi, tetapi mencakup juga semua subjek ekonomi seperti produsen, distributor, maupun konsumen baik dilakukan secara perorangan, kelompok, organisasi ataupun badan hukum. Sementara pengertian yang ketiga aadalah berjiwa koperasi, artinya yang terpenting adalah bahwa di semua bentuk-bentuk usaha koperasi, perseroan, dan/atau badan usaha milik negara selalu harus berjiwa koperasi yang di dalamnya terdapat usaha bersama berdasarkan asas kekeluargaan. Misalnya, meskipun bentuk usahanya adalah perusahaan swasta, akan tetapi karyawan diberikan peluang untuk memiliki perusahaan dalam bentuk kepemilikan saham, maka hal tersebut bisa dianggap memiliki jiwa koperasi.

Selanjutnya, kata 'usaha bersama' dapat diartikan sebagai usaha berjamaah, yang dalam bahasa ekonominya disebut mutualism, melalui perserikatan ini, yang berarti menolak individualisme atau asas perorangan. Demikian pula dengan kata 'asas kekeluargaan' yang dalam bahasa ekonominya disebut brotherhood, yang dalam bahasa agamanya disebut ukhuwah, baik persaudaraan secara agama, kemanusiaan, maupun bangsa. Kehidupan bermasyarakat dimana sektor ekonomi termasuk di dalamnya adalah merupakan prinsip-prinsip dasar yang sangat dianjurkan dalam Islam.

Istilah 'usaha bersama' dan 'asas kekeluargaan' sering dikaitkan dengan kata kerjasama dan persaudaraan. Salah satu prinsip dasar ekonomi Islam setelah tauhid menurut Abu Sulayman (1968) adalah persaudaraan (brotherhood). Prinsip persaudaraan yang terkandung dalam ajaran Islam dapat membentuk karakter masyarakat Muslim untuk saling memandang dengan posisi yang sama dan saling kerjasama (Lihat QS Al-Hujurat: 10).

Ekonomi Islam secara instrumental demi memperkuat persaudaraan di tengah masyarakat Muslim menganjurkan adanya zakat, infak dan sedekah untuk memperkuat ikatan persaudaraan mereka sekaligus untuk mengurangi kesenjangan ekonomi di antara mereka. Dalam konteks aktivitas ekonomi, ekonomi Islam memperkenalkan konsep kerjasama usaha yang biasa disebut mudharabah dan musyarakah. Bentuk kerjsama aktivitas ekonomi ini adalah merupakan nilai instrumental sistem ekonomi Islam untuk membangun perekonomian yang seimbang tanpa adanya eksploitasi.

Pengertian 'usaha bersama' kadang direduksi maknanya dalam bentuk mikro dan sempit, yaitu dikaitkan dengan koperasi sebagai bentuk usaha bersama. Hal ini tentunya tidak salah, tetapi pengertian ini menafikan bahwa bentuk usaha dalam perekonomian Indonesia bukan hanya koperasi saja. Penafsiran mikro ini merujuk pada Bung Hatta sebagai salah satu pencetus dari Pasal 33 ini yang kemudian bentuk konkritnya diterjemhakan sebagai koperasi.

Secara historis gagasan tentang koperasi sebagai soko guru perekonomian digagas oleh Bung Hatta. Koperasi adalah wujud konkrit dari "usaha bersama berdasarkan atas asas kekeluargaan". Koperasi menurut Bung Hatta dianggap sebagai soko guru perekonomian karena: (i) Koperasi mendidik self-helping; (ii) Koperasi mempunyai sifat kemasyarakatan di mana kepentingan masyarakat harus lebih diutamakan daripada kepentingan diri dan golongan sendiri; (iii) Koperasi digali dari budaya asli bangsa Indonesia; (iv) Koperasi menentang segala bentuk individualisme dan kapitalisme.

Hal ini menunjukkan bahwa secara ideologi, Bung Hatta ingin membangun sebuah sistem ekonomi yang sesuai dengan watak bangsa Indonesia yang religious dan memiliki nilai-nilai yang luhur yang menjunjung tinggi prinsip dan cita-cita tolong 
menolong, persaudaraan dan kerjasama, bukan mementingkan diri sendiri sekuler dan ateistis (Lihat QS. Al Maidah: 2 dan at-Taubah: 71).

Ayat-ayat al-Quran dan al-Hadist di atas menerangkan secara tegas pentingnya sikap saling tolong menolong di antara sesama manusia. Ia menjadi elemen penting dalam membangun hubungan sosial yang harmonis, integrasi antar semua elemen masyarakat dan memperkuat solidaritas sosial. Bahkan Hadist di atas menganggap seorang mukmin sebagai sebuah bangunan yang saling menyangga, dan tentunya sifat dan akhlak saling tolong menolong adalah elemen perekatnya. Sehingga bisa dikatakan bahwa asas kekeluargaan dalam redaksi UUD 1945 memiliki semangat dan cita-cita yang sama dengan ajaran-ajaran Islam atau maqashid syariah.

Islam secara terang-terang melarang umatnya untuk tidak berbuat dzalim demi untuk meraup keuntungan sendiri, yang mana berlawanan dari asas kekeluargaan sebagaimana tercantum dalam UUD 1945 (Lihat QS An-Nisaa: 29).

Untuk memperkuat nilai kekeluargaan dan kerjasama di tengah-tengah masyarakat, Islam memperkenalkan beberapa instrumen yang harus dilakukan, yaitu zakat, infak dan sedekah. Instrumen religius ini bertujuan untuk memperkuat bangunan solidaritas sosial sehingga terwujud masyarakat yang berdiri di atas asas kekeluargaan dan kebersamaan serta tolong-menolong (QS Al-Baqarah: 267).

Dalam pandangan ekonomi Islam memang tidak secara spesifik mengatur bentuk usaha dalam perekonomian. Usaha bisa dilakukan secara perorangan, kelompok, organisasi maupun badan hukum. Yang diatur secara detail dalam ekonomi Islam adalah nilai-nilai dan prinsip-prinisp umum yang harus diterapkan oleh para pelaku ekonomi dalam menjalankan aktivitas usahanya.

Pasal 33 Ayat (2) UUD 1945 menyatakan "Cabang-cabang produksi yang penting bagi negara dan yang menguasai hajat hidup orang banyak dikuasai oleh negara". "Dikuasai oleh negara" dimaknai sebagai penguasaan dalam arti yang luas. Penguasaan di sini bisa berarti kepemilikan dalam arti publik dan termasuk kekuasaan dalam mengendalikan dan mengelola bidang-bidang usaha secara langsung oleh pemerintah. Kata "penguasaan" itu tidak bisa diartikan sebagai kepemilikan seratus persen. Artinya, meskipun sebagian sahamnya tidak dimiliki oleh pemerintah, tetapi perusahaan itu tetap dikuasai oleh pemerintah. Sementara yang dikuasai oleh negara adalah "cabang produksi yang penting bagi negara dan menguasai hajat hidup orang banyak".

Pasal 33 (2) UUD 1945 ini menunjukkan pentingnya intervensi pemerintah dalam pengelolaan sumber daya ekonomi yang strategis dan penting untuk dikuasai oleh negara untuk digunakan atas nama rakyat dan digunakan sepenuhnya untuk kepentingan dan kesejahteraan masyarakat. Jika diberikan kebebasan kepada sektor swasta, maka dikhawatirkan digunakan untuk meraup keuntungan yang sebesarbesarnya tanpa memperhatikan kepentingan masyarakat secara umum. Berdasarkan pada maksud ini, Al Ghazali sebagaimana dikutip oleh Al-Arif (2011) secara moral mengimbau untuk tidak mencari keuntungan pada penjualan barang-barang pokok dengan mengatakan:

"Karena makanan adalah kebutuhan pokok, perdagangan makanan harus seminimal mungkin didorong oleh motif mencari keuntungan untuk menghindari eksploitasi melalui pengenaan harga yang lebih tinggi dan keuntungan yang lebih besar. keuntungan semacam ini seyogyanya dicari dari barang-barang yang bukan merupakan kebutuhan pokok."

Kandungan makna Pasal 33 (2) sebenarnya menjelaskan tentang sistem kepemilikan dalam perekonomian. Berdasarkan pada pasal tersebut, konstitusi ekonomi Indonesia mengakui adanya kepemilikan individu atas faktor-faktor produksi atau 
sumber daya ekonomi, kecuali sumber daya ekonomi yang menguasai hajat hidup orang banyak, dikuasai oleh negara. Ini menunjukkan bahwa UUD 1945 mengakui adanya jenis kepemilikan individu dan kepemilika negara atas sumber daya ekonomi. Jika dilihat dari perspektif ekonomi Islam, kepemilikan (al-milkiyah) sumber daya ekonomi dibagi menjadi tiga (An-Nabhani, 1996), yakni: kepemilikan individu, kepemilikan umum, dan kepemilikan negara.

Ekonomi Islam, sebagaimana juga konstitusi ekonomi Indonesia, tidak mengakui kepemilikan sepenuhnya hanya pihak individu atau swasta seperti yang berlaku pada sistem kapitalisme, atau kepemilikan sepenuhnya hanya dimiliki oleh negara atas nama rakyat sebagaimana berlaku pada sistem sosialisme. Kepemilikan oleh individu terhadap sumber-sumber ekonomi menjadi insentif bagi setiap orang untuk bekerja dan mengembangkan kekayaan/harta. Sementara kepemilikan umum dan kepemilikan negara dilandasai pada tujuan syariah.

Fungsi negara dalam perspektif ekonomi Islam sangat penting dalam menciptakan perimbangan dan pemerataan kekayaan dan pendapatan. Negara memiliki tanggung jawab untuk mencegah terjadinya ketimpangan dan ketidakadilan dalam penguasaan dan pendistribusian sumber daya ekonomi. Maksud ini sejalan dengan hadist Nabi SAW: "Imam adalah (laksana) pengembala (pelayan). Dan dia akan dimintai pertanggungjawaban terhadap urusan rakyatnya" (HR Bukhari).

Agar negara dapat melaksanakan kewajibannya, maka negara diberikan kekuasaan untuk mengelola harta kepemilikan umum dan kepemilikan negara dan tidak mengijinkan bagi individu atau swasta untuk mengambil dan memanfaatkannya demi meraup keuntungan sebesar-besarnya. Kepemilikan umum menurut pandangan sistem ekonomi Islam dapat dibagi menjadi tiga, yakni (Triyono, 2011): barang kebutuhan umum, barang tambang yang besar, dan sumber daya alam, yang sifat pembentukannya menghalangi untuk dimiliki individu. Sementara, kepemilikan negara adalah harta yang tidak termasuk kategori milik umum melainkan milik pribadi, namun barang-barang tersebut terkait dengan hak kaum Muslimin secara umum. Pengelolaannya menjadi hak sepenuhnya dari pemerintah atas dasar kepentingan masyarakat secara umum. Harta jenis ini dalam konteks ekonomi Islam adalah seperti jizyah, ghanimah, fa'i, kharaj, 'usyur, dan khumuz. Untuk konteks kontemporer yang menjadi harta milik negara adalah pajak, dividen dari badan usaha milik negara (BUMN), hibah, dan lain-lain.

Olehnya, semangat yang terkandung pada Pasal 33 (2) UUD 1945 yang mengatur tentang kepemilikan sumber daya ekonomi, terutama sumber daya ekonomi yang strategis dan menguasai hidup hajat orang banyak dikuasai oleh negara, sangat sejalan dengan tujuan dari ajaran Islam (maqashid syariah) yang mengharapkan terciptanya pemerataan kekayaan dan pendapatan di tengah-tengah masyarakat. Negara diharapkan dapat berperan secara startegis dalam menciptakan distribusi kekayaan ekonomi secara adil dan merata kepada rakyatnya melalui pengelolaan dan penguasaan sumber daya ekonomi strategis untuk kepentingan masyarakat umum.

Pasal 33 Ayat (3) UUD 1945 menentukan "Bumi dan air dan kekayaan alam yang terkandung di dalamnya dikuasai oleh negara dan digunakan untuk sebesar-besar kemakmuran rakyat". Maksud dari ayat ini adalah penguasaan oleh negara atas segenap sumber daya yang terdapat di dalam bumi, air, wilaya udara Indonesia serta segenap kekayaan yang terkandung di dalamnya, haruslah dipergunakan hanya sebesarbesarnya kemakmuran seluruh rakyat, bukan hanya kemakmuran untuk orang perorang. Tujuan akhir dari kegiatan ekonomi yang pokok justru adalah terwujudnya ide masyarakat adil dan makmur berdasarkan amanat dari UUD 1945. Dengan demikian, yang harus mendapat manfaat dari usaha pemanfaatan kekayaan alam yang tersedia itu 
adalah seluruh rakyat. Kepemilikan perseorangan, dalam perspektif ekonomi Islam, tidak diperbolehkan pada sumber-sumber daya ekonomi yang menyangkut kepentingan umum atau berhubungan dengan hajat hidup orang banyak. Sumber-sumber ekonomi tersebut menjadi miliki bersama, atau milik umum, atau negara. Menurut mayoritas ulama, sumber daya alam yang strategis tidak bisa dijadikan sebagai milik pribadi, harus dijadikan sebagai milik bersama yang penggunaan dan pemanfaatannya untuk kepentingan seluruh masyarakat. Secara detail, Rasulullah mengemukakan contoh bentuk jenis sumber daya ekonomi yang harus dijadikan milik bersama, "Semua orang Islam berserikat dalam tiga hal; dalam hal air, rumput dan api, dan garam" (HR Ahmad dan Abu Dawud)

Sementara itu, Pasal 33 Ayat (4) UUD 1945 berbunyi "Perekonomian nasional diselenggarakan berdasar atas demokrasi ekonomi dengan prinsip kebersamaan, efisiensi-berkeadilan, berkelanjutan, berwawasan lingkungan, kemandirian, serta dengan menjaga keseimbangan kemajuan dan kesatuan ekonomi nasional". Konsep demokrasi ekonomi yang terkandung dalam Pasal 33 (4) tersebut menempatkan pengutamaan kepentingan rakyat, khususnya hajat hidup orang banyak, yang bersumber pada kedaulatan rakyat atau demokrasi. Format demokrasi yang ingin dikembangkan di Indonesia bukan demokrasi liberalisme dan individualieme seperti yang berkembang di negara-negara Barat, tetapi demokrasi yang didasari pada kebersamaan yang berdasarkan pada sikap saling tolong-monolong (ta'awun), persaudaraan (ukhuwah), dan kerjasama, bukan mengutamakan persaingan (free competition).

Prinsip kebersamaan dan kekeluargaan menjadi hal utama dalam pengelolaan ekonomi negara. Kepentingan masyarakatlah yang diutamakan, bukan kepentingan orang-per orang, namun hal-hal dan harkat martabat individu orang per orang tetap dilindungi dan dihargai. Pandangan seperti ini sangat jelas sesuai dengan nilai-nilai dan ajaran Islam yang menghormati manusia dan menekankan masalah persaudaraan.

Perekonomian nasional selanjutnya dibangun di atas prinsip efisiensiberkeadilan, berkelanjutan, berwawasan lingkungan, kemandirian dan keseimbangan. Efisiensi-berkeadilan sebagaiman dimaknai oleh Jimly Asshiddiqie (2010) adalah bahwa untuk memajukan dan menciptakan etos kerja dikalangan para pelaku ekonomi perlu diciptakan iklim persaingan yang sehat di antara mereka untuk mewujudkan efisiensi ekonomi, akan tetapi efisiensi ini dalam bingkai untuk mencapai keadilan. Persaingan sekaligus melindungi kepentingan orang-orang lemah (prinsip keadilan) sangat selaras dengan nilai dan ajaran Islam. Islam mendorong terjadinya persaingan yang berbasiskan pada saling tolong menolong dan juga mendorong terjadinya keadilan.

Sementara itu, ayat terakhir dari Pasal 33 UUD 1945 itu adalah Ayat (5) yang berbunyi, "Ketentuan lebih lanjut mengenai pelaksanaan pasal ini diatur dalam undangundang". Semua ketentuan yang terkandung dalam Pasal 33 UUD 1945 itu berisi kebijakan-kebijakan konstitusional mengenai perekonomian nasional, yang rinciannya serta operasionalisasinya masih perlu dijabarkan secara konkrit dan dapat dijadikan pedoman yang secara hukum mengikat secara umum. Artinya, DPR bersama pemerintah masih harus menjabarkan kebijakan konstitusional di bidang perekonomian nasional dalam bentuk undang-undang sebagai produk legislasi. Namun demikian, jika terdapat produk-produk legislasi atau kebijakan pemerintah yang bertentangan dengan konstitusi ekonomi maka bisa diajukan judical review ke Mahkamah Konstitusi untuk dibatalkan dangan dinyatakan tidak sah dan tidak berlaku lagi. 


\section{Pasal 34 UUD 1945}

Pasal 34 UUD 1945 mengandung 4 ayat. Pasal 34 memperkuat peran negara dalam perekonomian, khususnya dalam hal perlindungan terhadap fakir miskin dan anak-anak terlantar melalui, penyediaan sistem jariangan sosial bagi seluruh rakyat Indonesia. Pasal ini juga mewajibkan negara untuk atas penyediaan fasilitas-fasilitas umum yang berkaitan dengan kepentingan masyarakat umum, seperti kesehatan, pendidikan, infrastruktur, dan sebagainya.

Adapun kandungan ayat dari Pasal 34 UUD 1945 adalah sebagai berikut:

(1) Fakir miskin dan anak-anak yang terlantar dipelihara oleh negara;

(2) Negara mengembangkan sistem jaringan sosial bagi seluruh rakyat dan memperdayakan masyarakat yang lemah dan tidak mampu sesuai dengan martabat kemanusiaan;

(3) Negara bertanggung jawab atas penyediaan fasilitas pelayanan kesehatan dan fasilitas pelayanan umum yang layak; dan

(4) Ketentuan lebih lanjut mengenai pelaksanaan pasal ini diatur dalam undangundang.

Pasal 34 Ayat (1) menyatakan, "Fakir miskin dan anak-anak yang terlantar dipelihara oleh negara". Artinya, konstitusi negara memerintahkan negara untuk menjamin kelangsungan hidup terhadap (setidaknya) tiga golongan, yaitu kaum fakir dan miskin dan anak-anak yang terlantar. Negara memiliki kewajiban mengikat untuk melindungi hak-hak, khususnya hak hidup dari orang-orang miskin, fakir dan anak-anak yang terlantar.

Dalam prakteknya, menurut Asshiddiqie (2010), tidak mungkin semua orang yang fakir, miskin dan anak terlantar dipelihara langsung oleh institusi atau badanbadan atau petugas-petugas pemerintahan. Partama, sudah sejak lama, bahkan sebelum kemerdekaan Republik Indonesia, sudah hadir lembaga-lembaga sosial yang melakukan pemeliharaan terhadap anak yatim dan terlantar serta orang fakir dan miskin. Misalnya, institusi-institusi keagamaan, seperti lembaga zakat, infak dan shadaqah sudah berkemban sejak masa awak perkembangan agama Islam di Indonesia. Kegiatankegiatan lembaga swasta tersebut tidak perlu "dinegarakan" semuanya. Kedua, jumlah orang fakir, miskin dan anak terlantar banyak sekali, tidak mampu sepenuhnya ditangani oleh pemerintah. Artinya, negara bisa mengembangkan berbagai macam cara baik terlibat secara lagsung ataupun tidak, asalkan kekuasaan negara tidak hilang dan beban tanggungjawab negara tidak dilupakan. Selain itu, pemeliharaan terhadap tiga golongan tersebut dapat pula dilakukan dengan sistem asuransi dan jaminan sosial.

Berdasarkan pada isi Pasal 34 Ayat (1) UUD 1945 serta penjelasannya di atas, semangat yang terkandung dalam konstitusi ekonomi tersebut sangat sesuai dengan ajaran Islam terutama pada keberpihakannya terhadap perlindungan kaum lemah, fakir dan miskin. Dalam ajaran Islam, negara memiliki kewajiban untuk melindungi kepentingan orang-orang yang tidak mampu dari eksploitasi orang-orang kuat.

Salah satu penekanan dalam ekonomi Islam adalah keberpihakan terhadap golongan lemah, seperti kaum fakir dan miskin serta orang tidak mampu. Ajaran Islam menempatkan negara sebagai pihak yang harus melindungi hak-hak mereka, khususnya berhubungan dengan pemenuhan kebutuhan dasar mereka. Bahkan, Islam tidak hanya menempatkan negara sebagai pihak yang bertanggungjawab, tetapi juga seluruh umat Muslim yang mampu diwajibkan untuk membantu mereka, melalui mekanisme zakat, infak dan sedekah.

Adanya perbedaan dalam kemampuan serta perbedaan dalam kesempatan dapat diduga sebagai sebab-musabab dari perbedaan dalam rezeki yang meungkin diterima 
oleh seseorang. Perbedaan tingkatan kemampuan serta spesialisasi menunjukkan keterbatasan kemampuan yang dimiliki oleh masing-masing orang dalam kehidupan pada umumnya, dan proses produksi khususnya. Di samping itu orang menghadapi kenyataan keterbatasan dalam kesempatan, baik karena waktu maupun karena kemampuan yang dimiliki oleh seseorang. Konsekuenisnya adalah lahirnya golongan kaya dan miskin dalam masyarakat.

Islam memiliki prinsip-prinsip tersendiri di dalam memandang masalah kayamiskin serta cara yang harus ditemput untuk mengatasi masalah tersebut, yaitu Saefudin, 1987): (i) Bahwa dalam hidup ini orang diharuskan untuk saling kenalmengenal dan bantu-membantu. (ii) Seorang mukmin dengan yang lain adalah bersaudara, dan selayaknya dapat merasakan penderitaan yang lain. Dalam sebuah hadist Rasululullah SAW berkata, "Perumpamaan orang-orang mukmin dalam hubungan kasih sayang di antara mereka adalah seperti satu badan; apabila salah satu anggota badan merasa sakit, maka seluruh badan ikut merasakannya dengan rasa panas dan tidak dapat tidur". (iii) Umat Islam diwajibkan memperhatikan dan membantu orang miskin dan orang-orang yang dalam kesulitan. (iv) Islam selalu mendorong umat untuk selalu beramal dan bersedekah. (v) Bahwa setiap Muslim wajib membayar zakat, sesuai dengan ketentuan-ketentuan yang berlaku.

Secara umum Pasal 34 Ayat $(1,2,3,4)$ UUD 1945, menjelaskan tentang peran negara dalam perekonomian khususnya dalam melindungi kehidupan orang-orang yang lemah, seperti orang yang fakir dan miskin dan anak-anak yang terlantar dalam memenuhi kehidupan dasar mereka. Untuk menjamin hal tersebut negara mengembangkan sistem jaringan sosial untuk memberdayakan masyarakat yang lemah. Pasal tersebut juga memberikan tanggung jawab kepada negara untuk menyediakan fasilitas umum yang layak bagi seluruh rakyatnya.

Salah satu elemen penting menurut ekonomi Islam adalah negara. Negara memiliki beberapa tanggung jawab terkait dalam memberikan jaminan sosial dan keseimbangan sosial. Menurut Abu A'la Al-Maududi (1990), negara diberi tanggung jawab untuk menjamin kebutuhan-kebutuhan pokok hidup, sandang, pangan, papa, kesehatan, dan pendidikan, bagi semua warga negara tanpa pembedaan ras atau agama, kepada yang mungkin tidak mampu, baik untuk sementara maupun selamanya; untuk memperolehnya karena menganggur, sakit atau alasan-alasan lainnya. Sementara itu, penguasa sebagai pihak yang bertanggung jawab atas kekayaan umum menurut Umar bin Khattab layaknya sebagai seorang pengasuh anak yatim. Artinya, kekayaan umum seperti anak yatim yang tidak dapat digunakan langsung dengan sepengetahuan pemiliknya, sebab pemiliknya adalah rakyat yang pengaturannya diwakilkan kepada penguasa di negara Islam.

Bahkan lebih jauh Islam mengatur secara terperinci bagaimana cara menjamin kelangsungan hidup orang-orang miskin, yaitu melalui instrumen zakat, infak dan sedekah. Islam membebankan kewajiban bagi setiap individu yang memiliki kekayaan yang sudah memenuhi nasab dan kepemilikannya sudah lebih dari satu tahun untuk mengeluarkan zakatnya yang diperuntukkan bagi orang-orang yang membutuhkan. Selain hal tersebut, Islam juga menganjurkan untuk banyak berinfak demi menegakkan saling tolong-monolong dan peduli antar sesama terutama bagi mereka yang kekuarangan secara ekonomi.

Peran negara yang termaktub pada Pasal 34 UUD 1945 terutama dalam menjamin kehidupan orang-orang lemah dan penyedian fasilitas umum sangat sejalan dengan peran negara dalam konsep ekonomi Islam. Menurut Muhammad Baqir Ash 
Shadr (2008) tanggung jawab negara dalam ekonomi Islam terdiri dari penyediaan jaminan sosial dan keseimbangan sosial.

\section{Jaminan Sosial}

Islam telah menugaskan negara untuk menyediakan jaminan sosial guna memelihara standar hidup seluruh individu dalam masyarakat Islam. Lazimnya, negara menunaikan kewajibannya ini dalam dua bentuk. Pertama, negara memberi individu kesempatan yang luas untuk melakukan kerja produktif, sehingga ia bisa memenuhi kebutuhan hidupnya dari kerja dan usahanya sendiri. Namun, jika negara tidak mampu menyediakan pekerjaan buat mereka, maka berlakulah bentuk yang kedua di mana negara mengaplikasikan prinsip jaminan sosial dengan cara menyediakan uang dalam jumlah yang cukup untuk membiayai kebutuhan individu tersebut dan untuk memperbaiki standar hidupnya.

Prinsip jaminan sosial didasarkan pada dua basis doktrin ekonomi Islam, yakni; kewajiban timbal balik masyarakat dan hak masyarakat atas sumber daya (kekayaan) publik yang dikuasai oleh negara. Islam telah mewajibkan (fardhu al kifayah) setiap muslim untuk saling tolong menolong. Negara punya hak memaksa terhadap setiap individu yang ada di bawah kekuasaanya untuk melaksanakan kewajiban agamanya. Islam mengaitkan jaminan sosial dengan prinsip umum persaudaraan Islam guna menunjukkan bahwa kewajiban tersebut bukanlah semacam pajak penghasilan khusus, melainkan sebuah ekspresi praktis dari persaudaraan di antara sesama Muslim. Sehingga kerangka moral Islamnya adalah hak seorang individu atas bantuan dan pemeliharaan individu lain beroleh pengertian islaminya dari rasa persaudaraan dan pertalian dalam keluarga besar manusia yang berkeadilan.

Basis lain dari aplikasi jaminan sosial adalah hak masyarakat atas sumbersumber kekayaan. Dasar teoritis dari gagasan ini adalah pengakuan Islam terhadap hak masyarakat atas seluruh sumber kekayaan (alam), karena seluruh sumber kekayaan alam telah diciptakan bagi masyarakat secara keseluruhan, bukan hanya untuk sekelompok orang. "Dialah Allah, yang menjadikan segala yang ada di bumi untuk kalian....".

Maksudnya, setiap individu berhak atas pemanfaatan kekayaan alam dan berhak atas hidup yang layak berkat manfaat tersebut. Jadi siapa saja yang mampu bekerja, negara harus memberinya kesempatan keraja. Sementara, bagi mereka yang tidak mampu bekerja, negara wajib memberinya manfaat kekayaan alam dengan menyediakan berbagai sarana bagain agar dapat mempertahankan standar hidup yang layak. Demikianlah tanggung jawab negara berkenaan hak masyarakat atas kekayaan alam. Penjelasan-penjelasan di atas sangat sejalan dengan Pasal 34 Ayat (1 dan 2) UUD 1945.

Berdasarkan pada doktrin ekonomi Islam tersebut agar negara menjamin pemenuhan hak bagi seluruh rakyatnya termasuk mereka yang fakir, miskin dan anak terlantar adalah dengan menciptakan sektor publik Islam yang dibiayai dari sumbersumber keuangan publik dan properti negara. Hal ini sejalan dengan Pasal 34 Ayat (3), terkait kewajiban negara dalam menyediakan fasilitas umum bagi seluruh rakyatnya.

\section{Keseimbangan Sosial}

Pada prinsipnya, Islam mengakui adanya perbedaan tingkat kekayaan di antara masyarakat sebagai konsekuensi dari perbedaan bakat dan kemampuan di antara mereka. Yang diinginkan oleh Islam menurut Baqir Ash Shadr adalah keseimbangan sosial, yaitu keseimbangan standar hidup di antara para individu dalam masyarakat. Islam menjadikan keseimbangan sosial, yakni keseimbangan standar hidup, sebagai 
sasaran dan tujuan yang harus diperjuangkan oleh negara dengen sebaik-baiknya, dalam batasan-batasan kemapuan dan kapasitasnya.

Secara eksplisit, tujuan yang ingin dicapai oleh Islam di sini adalah memakmurkan setiap individu anggota masyarakat. Pemerataan kemakmuran adalah tujuan yang dibebankan oleh teks-teks kepada imam selaku kepala negara. Kemakmuran menurut Baqir Ash Shadr adalah keadaan dimana seseorang mampu menghidupi diri dan keluarganya, di mana ia sejajar dengan masyarakat umum, yang berarti dalam menjalani kehidupannnya ke depan ia memiliki pijakan yang sama dengan masyarakat umum, menikmati standar hidup yang sama dengan mereka tanpa ada kesulitan dan kesukaran. Pandangan ini sesuai dengan konstitusi ekonomi kita yang tercantum dalam Alinea IV Pembukaan UUD 1945 dan Pasal 33 dan 34.

Dalam menciptakan keseimbangan sosial, Islam tidak hanya memberlakukan pajak dan zakat saja, tetapi juga mewajibkan negara untuk memanfaatkan sektor-sektor publik guna mencapai tujuan tersebut. Dalam konteks negara Islam, pemerintah dapat mengambil kekayaan dan baitul mal untuk menciptakan keseimbangan sosial dengan menyejahterahkan orang-orang miskin dan meningkatkan taraf hidupnya. Al Quran merinci pemanfaatan fay' sebagai salah satu sumber pendapatan baitul mal.

\section{Pasal 27 Ayat (2)}

Pasal-pasal lain yang berkaitan dengan ekonomi yang ada dalam UUD 1945 adalah Pasal 23 tentang keuangan negara dan hal-hal yang terkait dan Pasal 27 Ayat 2 tentang pekerjaan dan peghidupan yang layak bagi kemanusiaan, dan Pasal 28 tentang hak asasi manusia. Bagian ini hanya akan membahas Pasal 27 Ayat (2) yang berkaitan dengan hak warga negara untuk mendapatka penghidupan yang layak.

Pasal 27 Ayat (2) UUD 1945 berbunyi, "Tiap-tiap warga negara berhak atas pekerjaan dan penghidupan yang layak bagi kemanusiaan". Dalam rangka hidup layak, seseorang atau suatu keluarga harus bekerja untuk menghidupi dan memenuhi kebutuhan dasarnya. Oleh karenanya, setiap warga negara berhak melakukan pekerjaan yang halal selama dilakukan dengan cara yang tidak bertentangan dengan hukum yang berlaku, atau melanggar hak orang lain. Setiap orang tidak boleh dihalangi untuk mendapatkan kesempatan pekerjaan dengan imbalan yang layak, adil dan tanpa diskriminasi.

Hak mendapatkan kesempatan bekerja adalah hak yang dijamin oleh konstitusi. Negara atau pihak siapa saja tidak boleh berlaku diskriminasi dalam pemberian kesempatan kerja. Semua warga negara memiliki kesamaan status dalam mendapatkan pekerjaan, meskipun memiliki latar belakang agama, suku, bahasa, ras dan budaya yang berbeda. Hak mendapatkan pekerjaan dan imbalan yang layak adalah hak asasi setiap manusia.

Secara normatif, agama Islam sebagaimana juga dalam konstitusi ekonomi mendorong setiap individu untuk bekerja demi memenuhi kebutuhan hidup diri sendiri dan keluarganya atau orang yang menjadi tanggungannya. Al Quran penuh dan sering serta berkali-kali mendesak manusia untuk bekerja. Semua insentif yang ada diperuntukkan untuk manusia agar dia terlibat dalam aktivitas yang produktif (Ahmad, 2006). Sikap Islam terhadap anjuran untuk bekerja dapat dilihat dari ayat-ayat Al Quran berikut ini:"

Selain ayat suci Al Quran, banyak Hadist juga yang mendesak manusia untuk bekerja, misalnya: "Harta yang paling baik adalah harta yang diperoleh lewat tangannya yang menginginkan kebaikan lewat produksi."

Menurut Abdil'ati sebagaimana dikutip Ahmad (2006), Islam sangat menghormati segala bentuk pekerjaan untuk menghasilkan sarana hidup, sepanjang 
tidak ada kesenonohan dan tindakan yang salah dan merugikan. Dalam sebuah hadist Rasulullah bersabda, "Sesungguhnya yang mengambil seutas tali, lalu memotong ranting pohon dan mengikatnya dengan tali pula, lalu menjualnya untuk memenuhi kebutuhan hidupnya dan menyedekahkannya adalah lebih baik daripada meminta-minta pada orang lain. Baik orang yang dia minta itu memberi ataupun menolak." (HR Bukhari dan Ibnu Majah)

Dalam konteks peran negara, menurut Baqir Ash Shadr (2008), negara selayaknya memberi individu kesempatan yang luas untuk melakukan kerja produktif, sehingga ia dapat memenuhi kebutuhan dasar dari kerja dan usahanya sendiri. Negara juga harus memastikan tidak terjadinya perlakuan tidak adil dan diskriminasi di tempat kerja dan tingkat upah atau gaji atas setiap pekerja. Bagi mereka karena suatu hal tertentu sehingga tidak dapat bekerja, maka negara berkewajiban untuk membiayai kebutuhan hidupnya dan memperbaiki standar hidupnya.

Yang menjadi hak setiap individu sebagaimana tercantum pada Pasal 27 Ayat (2) bukan hanya hak untuk mendapatkan pekerjaan, tetapi juga penghidupan yang layak. Setiap warga negara berhak hidup secara layak sesuai dengan standar atau kehidupan rata-rata di mana mereka menetap. Fungsi negara, sebagimana diungkapkan oleh Monzer Kahf (1991) adalah "guaranteeing a minimum level of living for all those whose own earning fall shorter than satisfying their basic needs". Pernyataan Kahf ini menunjukkan bahwa negara berkewajiban untuk menjamin standar hidup yang layak bagi mereka yang memiliki pendapatan di bawah dari kemampuan untuk memenuhi kebutuhan dasar hidupnya. Pendapat Kahf tentang peran negara dalam memberikan kehidupan yang layak bagi warganya sejalan dengan pendapat Baqir Ash Shadr yang menempatkan negara sebagai pihak yang berkewajiban untuk memberikan jaminan atas pemberian bantuan dan sarana agar individu bisa hidup sesuai dengan standar hidup masyarakat Islam (sesuai dengan standar hidup di mana mereka berada) dan mempertahankannya. Negara dapat menggunakan kekayaan negara untuk memberikan kelayakan hidup bagi masyarakatnya.

Berdasarkan pada argumentasi di atas, dapat disimpulkan bahwa Pasal 27 Ayat (2) yang berhubungan dengan hak setiap individu untuk mendapatkan pekerjaan dan penghidupan yang layak serta bagaimana peran negara untuk mewujudkannya sangat sesuai dengan teks-teks yang terkandung dalam Al Quran dan Al Hadist yang menganjurkan untuk berkerja dan mencari penghidupan yang layak. Peran negara dalam perekonomian dalam ajaran Islam juga menempatkan negara sebagai pihak yang berkewajiban untuk menyediakan pekerjaan dan penghidupan yang layak bagi warganya.

\section{SIMPULAN}

Undang-Undang Dasar suatu negara atau biasa disebut konstitusi negara tidak hanya terbatas sebagai dokumen politik, tetapi juga dokumen ekonomi yang setidak-tidaknya mempengaruhi dinamika perkembangan perekonomian suatu negara. Konstitusi ekonomi menjadi hukum tertinggi dan harus dijadikan sebagai acuan dan rujukan dalam setiap pengembangan kebijakan ekonomi. Jika terjadi pertentangan antara undangundang, peraturan ataupun kebijakan dengan konstitusi ekonomi (UUD 1945) maka dapat dibatalkan melalui mekanisme judical review melalui Mahkamah Konstitusi.

Konstitusi ekonomi Indonesia tertuan dalam beberapa pasal yang ada dalam UUD 1945, khususnya Pasal 33, 34, 23, 27 dan 28. Bahkan Alinea IV Pembukaan UUD 1945 
yang berisi prinsip-prinsip dasar Pancasila dan Tujuan Bernegara secara tidak langsung juga mengandung gagasan mengenai kesejahteraan sosial dan eonomi.

Jika dilihat dari segi sistem ekonomi, ekonomi Indonesia tidak bisa sepenuhnya dikatakan menganut sistem kapitalisme ataupun sosialisme ataupun gabungan dari kedua dari sistem tersebut (mixed economy). Misalnya dari segi kepemilikan sumber daya ekonomi atau faktor-faktor produksi, tak terdapat alasan untuk mengatakan bahwa sistem ekonomi Indonesia adalah kapitalisme. Sama halnya, tidak terdapat argumentasi yang cukup untuk mengatakan, bahwa Indonesia menganut sistem ekonomi sosialis. Indonesia mengakui kepemilikan individual atas faktor-faktor produksi, kecuali untuk sumber daya-sumber daya yang menguasai hidup orang banyak, dikuasai oleh negara.

Kemunculan ekonomi Islam belakangan yang secara historis memiliki perbedaan dengan sistem kapitalisme dan sosialisme dipandang memiliki banyak kesamaan dengan konstitusi ekonomi Indonesia yang tertuang dalam beberapa pasal yang ada dalam UUD 1945. Secara garis besar dalam konstitusi ekonomi khususnya Pasal 33 mengatur tentang asas dasar perekonomian Indonesia yang berdasarkan pada asas kekeluargaan, bukan kompetisi murni. Juga mengatur sistem kepemilikan yang mengakui adanya kepemilikan individu dan kepemilikan bersama. Di Pasal yang sama juga ditekankan perlunya intervensi negara dalam penguasaan sektor-sektor ekonomi yang strategis yang penggunaannya untuk kemakmuran masyarakat Indonesia. Di sisi yang sama, ekonomi Islam sangat mengedepankan prinsip kebersamaa, persaudaraan dan tolong meolong sebagai asas utama dalam aktivitas ekonomi. Ekonomi Islam memperkenalkan sistem bagi hasil yang memiliki kesamaan dengan bentuk usaha kekeluargaan yang disebut sebagai koperasi. Begitupula dengan sistem kepemilikan, ekonomi Islam mengakui adanya kepemilikan individu dan bersama, akan tetapi ekonomi Islam secara spesifik mengatur tatacara memperolehnya dan pemanfaatannya. Sstem ekonomi Islam menempatkan negara sebagai salah satu variabel penting dalam perekonomian baik dalam bentuk intervensi kebijakan maupun sebagai pelaku ekonomi.

Ekonomi Islam juga memiliki perhatian yang tinggi terhadap golongan yang tidak mampu, seperti fakir miskin dan anak-anak yang terlantar. Bahkan ekonomi Islam menyediakan sistem untuk melindungi hak-hak mereka melalui mekanisme infak, sedekah dan zakat begitupula dengan kehadiran lembaga-lembaga keuangan seperti BMT dan micro finance lainnya. Di sisi lain negara punya kewajiban untuk menyediakan barang-barang publik untuk kesejahteraan masyarakat. Prinsip ekonomi Islam ini sangat sejalan dengan kandungan UUD 1945 Pasal 34.

Di samping itu pula saat ini sudah bermunculan undang-undang, peraturan dan kebijakan yang berhubungan dengan pengembangan ekonomi Islam di Indonesia yang secara langsung menunjukkan bahwa perangkat-perangkat regulasi yang mengatur eksistensi ekonomi Islam tidak bertentangan dengan konstitusi ekonomi. Karena jika bertentangan maka akan digugat di Mahkamah Konstitusi untuk dibatalakan pemberlakuannnya.

Oleh karenanaya tidak perlu ada usaha untuk membenturkan antara konstitusi ekonomi Indonesia dengan ekonomi Islam atau antara ekonomi pancasila dengan ekonomi Islam karena masing-masing sistem tersebut diinspirasi dari ajaran Islam. Hal tersebut terlihat pada adanya kesamaan prinsip dasar dan tujuan yang ingin dicapai.

\section{PUSTAKA ACUAN}

Abbas, Anwar. 2008. Bung Hatta dan Ekonomi Islam. Yogyakarta: Multi Pressindo 
Ahmad, Kurshid. 1997. "Pembangunan Ekonomi Dalam Perspektif Islam", dalam Etika Ekonomi Politik. Surabaya: Risalah Gusti

Ahmad, Mustaq. 2006. Etika Bisnis Dalam Islam. Jakarta: Pustaka Al Kautsar

Al Arif, M. N. R. 2011. Dasar-Dasar Ekonomi Islam. Surakarta: Era Adicitra

An Nabhani, Taqiyuddin. 1996. Membangun Sistem Ekonomi Alternatif. Surabaya: Risalah Gusti

Ash Shadr, M. Baqir. 2008. Buku Induk Ekonomi Islam "Iqtishaduna", edisi terjemahan Jakarta: Zahra

Asshiddiqie, Jimly. 2010. Konstitusi Ekonomi. Jakarta: Kompas

Chapra, Umar. 2000. Islam dan Pembangunan Ekonomi, edisi terjemahan. Jakarta: Gema Insani

Dumairy. 1996. Perekonomian Indonesia. Jakarta: Airlangga, 1996

Grossmen, Gregory. 1995. Sistem-sistem Ekonomi. Jakarta: Bumi Aksara

Gunadi, Tom. 1981. Sistem Perekonomian Menurut Pancasila dan UUD 1945. Bandung: Angkasa

Husaini, Adian. 2010. Pancasila bukan untuk Menindas Hak Konstitusional Umat Islam. Jakarta: Gema Insani Press

Kahf, Monzer. 1991. "Economic Role of State in Islam", lecture presented the seminar of Islamic economic, Dakka Bangladesh.

--.-. 1999. "Islamic Economic System - A Review", dalam An Introduction to Islamic Economics. New Delhi India: Kitab Bhavan.

Khaldun, Ibn. 2000. Mukaddimah, edisi terjemahan. Jakarta: Pustaka Firdaus

Limbong, Bernhard. 2011. Ekonomi Kerakyatan dan Nasionalisme Ekonomi. Jakarta: Margaretha Pustaka

Matta, Anis. 1997. "Sejarah Pemikiran Ekonomi Islam" dalam Wawasan Islam dan Ekonomi: Sebuah Bunga Rampai. Jakarta: Penerbit FE UI

Maududi, Abu A'la Al. 1990. Hukum dan Konstitusi Sistem Politik Islam. Jakarta: Mizan

Mubyarto. 1987. Ekonomi Pancasila, Gagasan dan Kemungkinan. Jakarta: LP3ES

Quthb, M. I. 2002. Kebijakan Ekonomi Umar Bin Khattab. Jakarta: Pustaka Azzam

Rahardjo, Dawam. 1997. "Ekonomi Islam, Ekonomi Pancasila dan Pembangunan Ekonomi Indonesia" dalam buku Etika Ekonomi Politik. Malang: Risalah Gusti

Saefuddin, A.M. 1987. Ekonomi dan Masyarakat dalam Perspektif Islam. Jakarta: Rajawali Press

Sanusi, Bachrawi. 2010. Sistem Ekonomi: Suatu Pengantar. Jakarta: Lembaga Penerbit FE UI

Sulayman, A., dan Abdul-Hamid A. 1968. "The Theory of The Economics of Islam: The Economics of Tauhid and Brotherhood", dalam Contemporary Aspects of Economic Thinking in Islam, Proceedings of the third East Coast Regional Conference of the Muslim Students' Association of the United States and Canada

Swasono, Sri-Edi. 2008. Bung Hatta dan Ekonomi Islam. Yogyakarta: Multi Pressindo "Workshop Nasional Arsitektur Ilmu Ekonomi Islam", UIN Syarif Hidayatullah Jakarta, Februari 2012.

Tambunan, Tulus. 2011. Perekonomian Indonesia: Kajian Teoritis dan Analisis Empiris. Bogor: Ghalia Indonesia Press

Triono, D. Condro. 2011. Ekonomi Islam Madzhab Hamfara. Yogyakarta: Irtikaz 